\title{
Influence of Phosphorous and Nitrogen Fertilizer Rate on Grain Yield of Rice at Kamashi Zone of Benshal-gul Gumuz Region, Ethiopia
}

\author{
Bekele Anbessa Fayisa*, Getahun Dereje Welbira \\ Ethiopian Institute of Agricultural Research, Assosa Agricultural Research Centre, Western Ethiopia, Ethiopia \\ Email address: \\ fbakalaanbessa@yahoo.com (B. A. Fayisa) \\ ${ }^{*}$ Corresponding author
}

\section{To cite this article:}

Bekele Anbessa Fayisa, Getahun Dereje Welbira. Influence of Phosphorous and Nitrogen Fertilizer Rate on Grain Yield of Rice at Kamashi Zone of Benshal-gul Gumuz Region, Ethiopia. Journal of World Economic Research. Vol. 5, No. 2, 2016, pp. 8-14.

doi: 10.11648/j.jwer.20160502.11

Received: May 24, 2016; Accepted: June 13, 2016; Published: June 21, 2016

\begin{abstract}
The scientific information available with regards to the response of upland rice to $\mathrm{N}$ and $\mathrm{P}$ fertilizers for its optimum production on nitosols of Kamashi zone is very limited. Therefore, a field experiment was conducted on nitosols of Kamashi, western Ethiopia to study the yield and yield components response of rice and to establish the optimum $\mathrm{N}$ and $\mathrm{P}$ fertilizer levels required for improved grain yield of upland rice. Field experiments were conducted at Kamashi locations, for two years at this location, to investigate the response of rice $\mathrm{N}$ and $\mathrm{P}$ fertilization. Four levels of $\mathrm{N}\left(0,46,92,138 \mathrm{~kg} \mathrm{ha}^{-1}\right)$ and four levels of $\mathrm{P}\left(0,10,20\right.$ and $\left.30 \mathrm{~kg} \mathrm{ha}^{-1}\right)$ were studied in factorial combinations in a randomized complete block design with triplicates. The results revealed substantial responses of rice to the main factors of $\mathrm{N}$ and $\mathrm{P}$ fertilization on grain yield, No. of panicle $/ \mathrm{m}^{2}$, No. of tiller/plant, No of tiller $/ \mathrm{m}^{2}$, and plant height. Rice grain yield, No. of panicle/m², No. of tiller/plant, No of tiller $/ \mathrm{m}^{2}$, and plant height increased significantly with increasing level of $\mathrm{P}$ and $\mathrm{N}(\mathrm{P}<0.001)$. The effects of $\mathrm{N}$ by $\mathrm{P}$ interaction were non-significant $(\mathrm{P} \leq 0.05)$ among the different yield and yield components studied except panicle length $(\mathrm{p}<0.05)$ and straw yield $(\mathrm{P}<0.01)$. Mean grain yield was significantly $(\mathrm{P}<0.001)$ enhanced by $16.2 \%$ with the application of $10 \mathrm{~kg} P$ ha ${ }^{-1}$, $23.6 \%$ with application $20 \mathrm{~kg} \mathrm{P} \mathrm{ha}^{-1}$ and 34.6 with the application of $30 \mathrm{~kg} \mathrm{P}^{-1}$ over zero-P (Table 2). High N at $138 \mathrm{~kg}$ ha ${ }^{-1}$ significantly $(\mathrm{P}<0.001)$ increased the yield of rice by $47.2 \%$, while $92 \mathrm{~kg} \mathrm{~N}^{-1}$ increased it by $36.2 \%$, and $46 \mathrm{~kg} \mathrm{~N}^{-1}$ increased the yield by $32.5 \%$ compared to $0 \mathrm{~kg} \mathrm{~N} \mathrm{ha}^{-1}$. There was no significant difference in grain yield between 46,92 and $138 \mathrm{~kg} \mathrm{~N} \mathrm{ha}^{-1}$. The magnitude of increase in grain yield over the control due to application of $46 \mathrm{~N}$ and $10 \mathrm{P}$ ha ${ }^{-1}$ were $32.5 \%$ and $16.2 \%$ higher over the control respectively. The partial budget analysis also indicated economic benefit for finger millet when it is fertilized with $46 \mathrm{~N}$ and $10 \mathrm{P} \mathrm{kg} \mathrm{ha}^{-1}$.
\end{abstract}

Keywords: Rice (Oryza Sativa L.), Fertilizers, Grain Yield, Nitrogen, Phosphorous

\section{Background}

The demand for rice far exceeds the production which in the last 30 years in Sub-Saharan Africa (SSA) has increased by $70 \%$ due mainly to land expansion and only $30 \%$ due to increase in productivity [10]. This increase in production, not withstanding, rice production has not kept pace with the demand as a result of rapid population growth. Grain yield as in most developing countries is as low as $0.5 \mathrm{mg} \mathrm{ha}^{-1}$ [3]. The low productivity arises from the use of low yielding varieties, pest and disease problems, inherently low soil fertility, and poor nutrient supply.

The cultivation of rice in Ethiopia is of more recent history than its utilization as a food crop. Some evidences indicate that cultivation of rice in Ethiopia was first started at the Fogera and Gambella plains in the early 1970s. Currently, the Fogera, Gambella, Metema, and Pawe plains located in the northern, northwestern, and western regions are developing in to major rice-producing areas in Ethiopia [7]. At the Fogera plain, rice plays an important role in relaxing the problem of food-insecurity of the farming community. 
Benishangul-Gumuz Regional State (BGRS) is one of the potential regions in Ethiopia with ample rainfall i.e. for six months and conducive environment which are suitable for rice production. It is estimated to be 4.9 million hectare of land is potential for rain fed rice production [22]. About two million hectare is highly suitable and the rests are suitable and moderately suitable both for upland and low land rice ecosystems.

Rice production in Kemashi zone was first realized by settler community through informal rice seed exchange from other regions. Following this, on station and on farm research activities were started a few years back under rain fed condition in other similar weredas of Assosa zone. Except the breeding, other research components like agronomic aspects of rice are found at infant stage. Across location, varietal selection research activities reveal that rice is a well adaptable commodity for the region because of long rainfall duration (MoA). The Agro ecology allows for several crops production and rice can be the main demand driven item for the areas.

Rice research activity has been conducted in the region for the past few years and some promising varieties have been adopted. Among the released NERICA varieties, NERICA-4 had better yield advantage over others under on-station and on-farm conditions (Assosa ARC, Completed activity Report). Yet, improvement of its production has not been possible due to low soil fertility and inadequate nutrient management among other factors [2]. Continuous cropping, high proportions of cereals in the cropping system, and the application of suboptimal levels of mineral fertilizers by farmers aggravates the situation in the area (MoA). These further imply the need for participatory evaluation and determination of optimum rate of $\mathrm{N}$ and $\mathrm{P}$ fertilizers for upland rice production and for the improvement of farmers' knowledge and skills on optimum utilization of inputs (fertilizers).

Therefore, the objective of the study was to determine the optimum of rate $\mathrm{N}$ and $\mathrm{P}$ fertilizer for upland rice (NERICA4 ) in the area in terms of yield increase and economic return and for evaluate the effects of applied $\mathrm{N}$ and $\mathrm{P}$ fertilizer rates on yield and yield components of upland rice (NERICA-4 variety) under Nitosol condition.

\section{Materials and Methods}

\subsection{Location and Time of Study}

A field experiment was conducted under rain fed conditions during the main rainy season (June to October) of 2014 and 2015 to investigate the effects of $\mathrm{N}$ and $\mathrm{P}$ fertilizers on grain yield and yield components of upland rice under research fields on nitosols of the Kamashi zone. Kamashi Wereda is one of the 5 Weredas found in Kamashi Zone with is capital also known as Kamashi town located at $560 \mathrm{~km}$ west of Addis Ababa and $246 \mathrm{~km}$ to the south east of Assosa. Its altitude ranges from 1000 to 1350 m.a.s.l. with annual rainfall of 900 to $1400 \mathrm{~mm}$. The temperature ranges from $20^{\circ} \mathrm{C}$ to $30^{\circ} \mathrm{C}$. The Wereda has a total area of $1595 \mathrm{~km}^{2}$ of which 71910 ha is cultivable land, 39950ha is forest land, 11186 ha is grazing land, 31960 ha is unusable land and the remaining 4794 ha is under construction for road, house, town etc. Agriculture is the main occupation and livelihood source of the area. Crop production is characterized by hoe based shifting cultivation with little oxen plow. The major crops grown are sorghum and maize mainly for home consumption while sesame and ground nut are grown for cash. Small ruminants, donkey, poultry and honey bee are the most important livestock species raised. There is huge coverage of forest resources which is composed of various tree species dominated by bamboo.

\subsection{Experimental Treatments, Design, and Procedures}

The fertilizer treatments considered in the study consisted of four levels of $\mathrm{N}\left(0,46,92\right.$, and $\left.138 \mathrm{~kg} \mathrm{~N} \mathrm{ha}^{-1}\right)$ and four levels of $\mathrm{P}\left(0,10,20\right.$ and $\left.30 \mathrm{~kg} \mathrm{Pha}^{-1}\right)$ and their complete factorial combinations. The experiment was then conducted using a factorial experiment laid out in a randomized complete block design with three replications consisting of a total of 16 treatments and 48 total plot per three replication or 16 plots per one replication. A $3 \mathrm{~m} \times 4 \mathrm{~m}\left(12 \mathrm{~m}^{2}\right)$ plot size was used as an experimental unit. A composite soil sample (0$30 \mathrm{~cm}$ ) was collected from the site for laboratory analysis before land preparation. The blocks were separated by a 1.5 $\mathrm{m}$ wide open space where as the plots within a block were separated by a $0.75 \mathrm{~m}$ wide space. Soil bunds were constructed around each plot and around the entire experimental field to minimize nutrient and water movement from plot to plot. Planting was made on 20 June 2014 to 2015 by hand drilling the seeds at a rate of $65 \mathrm{~kg} \mathrm{ha}^{-1}$ in rows spaced $30 \mathrm{~cm}$ apart. Nitrogen was applied in two equal splits, where in $50 \%$ of the $\mathrm{N}$ rate was applied basal at planting and the remaining half was top dressed at the maximum tillering stage which occurred 35-45 days after germination, as urea $(46 \% \mathrm{~N})$. Unlike $\mathrm{N}$, the total dose of $\mathrm{P}$ was applied basal as triple super phosphate $(20 \% \mathrm{P})$ during sowing. Weed control was manual mainly by hand picking. Crop growth was then monitored until harvest. Due to the frequent prevalence of vigorous growth and high infestation of weeds, the field was hand weeded four times at 20,35, 50, 65 and 90 days after sowing.

\subsection{Yield and Agronomic Data Collection and Analysis}

The whole agronomic parameters like date of emergence, date of heading, date of maturity, number of tiller per plant, plant height, panicle length, number of panicle per plant, number of effective tiller per plant, and yield per plot and kilogram per hectare were recorded. Number of tillers was counted after maximum tiller formation stage and mean number of tillers determined while plant height was measured at harvest. At maturity, an area of $1 \mathrm{~m}^{2}$ excluding border rows was measured out in each plot, number of panicles counted and harvested. Grain and Stover yield were measured and yield per hectare estimated. Panicles were also 
collected from non-border rows and mean individual weight per panicle determined. The whole trials have been harvested manually by collaboration of researchers, technical assistance and daily laborers and finally the seeds was properly cleaned and weighed and the data collected from the treatments were analyzed by STATISTIX 8 .

\subsection{Economic Data Collection and Analysis}

Economic analysis was performed to investigate the economic feasibility of the treatments (fertilizer rates). A partial budget, dominance and marginal analysis were used. The average yield was adjusted downwards to reflect the difference between the experimental plot yield. The average open market price (Birr kg ${ }^{-1}$ ) for rice and the official prices of $\mathrm{N}$ and $\mathrm{P}$ fertilizers were used for analys

\section{Results}

\subsection{Soil Physico-chemical Properties Before Sowing}

Nitosol is the major soil types found in all Weredas of Kamashi zone. This soil type occurs in high rainfall areas on flat to slopping terrains. It is dark reddish brown to dark red in color with deeply developed clay alleviation horizon of high structural stability. Nitisols are well drained, porous with high water holding capacity. The texture of these soils is clay-to-clay loam with moderate organic matter content and relatively easily weathering minerals. The soil used for this study ranges from very moderate acidic $(\mathrm{pH} 5.46)$ to the slightly acidic ( $\mathrm{pH}$ 5.71) class indicating the possibility of $\mathrm{Al}$ toxicity and deficiency of certain plant nutrients. The exchangeable $\mathrm{K}$ of the soil before the application of the treatments ranges from $0.46 \mathrm{cmol}(+) \mathrm{kg}^{-1}$ to $0.51 \mathrm{cmol}(+)$ $\mathrm{kg}^{-1}$. All experimental soils had adequate $\mathrm{K}$ content. According to Landon (1991), available (Bray II extractable) soil $\mathrm{P}$ level of less than $10 \mathrm{ppm}$ is rated as low, 11-31 ppm as medium and greater than $18 \mathrm{mg} \mathrm{kg}^{-1}$ is rated as high. Thus, both trial year had low to medium (bray II extractable) $\mathrm{P}$ (Table 1). Following the rating of total $\mathrm{N}$ of $>1 \%$ as very high, 0.5 to $1 \%$ high, 0.2 to $0.5 \%$ medium, 0.1 to $0.2 \%$ low and $<0.1 \%$ as very low $\mathrm{N}$ status as indicated by Landon (1991), the experimental soils qualify for low total $\mathrm{N}$. Similarly, the organic carbon (OC) content of the soil was also very low to low in accordance with Landon (1991), who categorized OC content as very low $(<2 \%)$, low $(2-4 \%)$, medium (4-10\%), high (10-20\%). The very low OC and low $\mathrm{N}$ content in the study area indicate low fertility status of the soil. This could be due to continuous cultivation and lack of incorporation of organic materials. (Table 1)

Table 1. Chemical analysis of some parameters of soil prior to cropping.

\begin{tabular}{|c|c|c|c|c|c|c|}
\hline Year depth & PH & $\% \mathrm{OC}$ & $\% \mathrm{~N}$ & ppmP & Meq. $\mathrm{K} / \mathbf{1 0 0 g}$ & $\begin{array}{l}\text { Meq. } \\
\text { CEC/100g }\end{array}$ \\
\hline $20140-30 \mathrm{~cm}$ & 5.71 & 1.476 & 0.11 & 10.8 & 0.51 & 22.6 \\
\hline $20150-30 \mathrm{~cm}$ & 5.46 & 1.870 & 0.17 & 9.8 & 0.46 & 23.2 \\
\hline
\end{tabular}

\subsection{Influence of Year, Phosphorus and Nitrogen on Yield and Yield Components of Upland of Rice}

Year had highly significant $(P<0.01)$ influence on all grain yield and yield components measured. The main effects of phosphorus was also highly significant $(P<0.01)$ on yield and yield components measured, except number of panicle per $\mathrm{m}^{2}$, number of tiller per plant and panicle length. Nitrogen had highly significant $(P<0.01)$ effects on all parameters measured, except panicle length (Table 1). Year had a significant influence on nitrogen as there was a significant year $\times$ nitrogen interaction on grain yield $(P<$ $0.05)$, number of tiller per plant $(P<0.05)$, number of tiller per $\mathrm{m}^{2}(p<0.01)$ and straw yield $(P<0.001)$ (Table $\left.1 \& 3\right)$. The mean squares due to $\mathrm{N} \times \mathrm{P}$ interactions were significant only for panicle length $(p<0.05)$ and straw yield $(p<0.01)$.

Table 2. Analysis of variance for yield and yield components of rice on nitosol of Kamashi at Benshal-gul Gumuz Regional State.

\begin{tabular}{|c|c|c|c|c|c|c|c|c|}
\hline \multicolumn{9}{|c|}{ Source of variation Mean squares } \\
\hline & Df & Grain yield & No. of panicle $/ \mathrm{m}^{2}$ & No. of tiller/plant & No. of tiller $/ \mathrm{m}^{2}$ & Plant height & Panicle length & Straw yield \\
\hline $\mathrm{N}$ & 3 & $1.479 * * *$ & $12785 * *$ & $5.0228 * *$ & $5833 * *$ & $466.05 * * *$ & $0.914 \mathrm{NS}$ & $61.088 * * *$ \\
\hline$P$ & 3 & $8946895 * * *$ & $1748^{\mathrm{NS}}$ & $1.080^{\mathrm{NS}}$ & $1579^{\mathrm{NS}}$ & $87.86^{* *}$ & $3.12^{\mathrm{NS}}$ & $28.595 * * *$ \\
\hline Year & 1 & $1.224 * *$ & $475314 * * *$ & $13.60 * * *$ & $405601 * * *$ & $3542.94 * * *$ & $242.88 * * *$ & $660.76^{* * *}$ \\
\hline $\mathrm{N} * \mathrm{P}$ & 9 & $2129549^{\mathrm{NS}}$ & $1084^{\mathrm{NS}}$ & $0.550^{\mathrm{NS}}$ & $1829^{\mathrm{NS}}$ & $10.76^{\mathrm{NS}}$ & $2.708^{*}$ & $9.500 * *$ \\
\hline $\mathrm{N}^{*}$ Year & 3 & $1453087^{*}$ & $2412^{\mathrm{NS}}$ & $1.7828 *$ & $4257 * *$ & $270.31 * * *$ & $0.775 *$ & $29.487 * * *$ \\
\hline$N^{*} P^{*}$ year & 6 & $782659^{\mathrm{NS}}$ & $466^{\mathrm{NS}}$ & $1.857^{\mathrm{NS}}$ & $1257^{\mathrm{NS}}$ & $13.45^{\mathrm{NS}}$ & $1.854 \mathrm{NS}$ & $6.458^{\mathrm{NS}}$ \\
\hline Errors & 62 & 1449946 & 1141 & 1.4029 & 1612 & 22.45 & 1.532 & 3.832 \\
\hline
\end{tabular}

ns-non significant. *, **, *** indicate significant difference at probability levels of 5\%, 1\% and $0.1 \%$ respectively.

\subsubsection{Influence of Year, Phosphorus and Nitrogen on Yield of Upland Rice}

Analysis of variance for two factors randomized complete block design (Table 2) revealed highly significant difference $(\mathrm{P}<0.001)$ due to the main effects of the levels of $\mathrm{N}$ and $\mathrm{P}$ application for the means of yield. However the mean squares due to $\mathrm{N} \times \mathrm{P}$ interactions were non-significant difference for the yield of upland rice. Mean grain yield was significantly $(\mathrm{P}<0.001)$ enhanced by $16.2 \%$ with the application of $10 \mathrm{~kg} \mathrm{P} \mathrm{ha}{ }^{-1}, 23.6 \%$ with application $20 \mathrm{~kg} \mathrm{P}$ $\mathrm{ha}^{-1}$ and 34.6 with the application of $30 \mathrm{~kg} \mathrm{P} \mathrm{ha}^{-1}$ over zero-P (Table 2). There was no significant difference observed between 20 and $30 \mathrm{~kg} \mathrm{P} \mathrm{ha}^{-1}$ (Table 2). Thus, the results of this investigation finding was disagreement with the works of 
[9] who reported that at higher levels of applied P, grain yield increased marginally or decreased due to the reduction in the number of filled spikelet and 1000 grain weight, particularly in soils with high soil test values of available P. Application of $\mathrm{P}$ slightly increased grain yield (Table 2). The highest grain yield of $5660 \mathrm{~kg} \mathrm{ha}^{-1}$ was recorded at the highest $\mathrm{P}$ rate of $30 \mathrm{Kg} \mathrm{ha}^{-1}$ and it was at par with $\mathrm{P}$ rate of $20 \mathrm{Kg} \mathrm{ha}^{-1}$. The lowest grain yield of $4205 \mathrm{~kg} \mathrm{ha}^{-1}$ was recorded in $\mathrm{P}$ rate of 0 $\mathrm{Kg} \mathrm{ha}^{-1}$. [6] reported that phosphorus deficiency in small grains is usually expressed as stunted growth.

Also, the yield of rice was significantly $(P<0.001)$ influenced by $\mathrm{N}$ rates. High $\mathrm{N}$ at $138 \mathrm{~kg} \mathrm{ha}^{-1}$ significantly $(P$ $<0.001$ ) increased the yield of rice by $47.2 \%$, while $92 \mathrm{~kg} \mathrm{~N}$ $\mathrm{ha}^{-1}$ increased it by $36.2 \%$, and $46 \mathrm{~kg} \mathrm{~N} \mathrm{ha}^{-1}$ increased the yield by $32.5 \%$ compared to $0 \mathrm{~kg} \mathrm{~N} \mathrm{ha}^{-1}$ (Table 2). There was no significant difference in grain yield between 46, 92 and $138 \mathrm{~kg} \mathrm{~N} \mathrm{ha}^{-1}$.

The same is true for nitrogen treatment application at kamashi zone of Benshal-gul gumuz. Application of $\mathrm{N}$ slightly increased grain yield (Table 2). The highest grain yield of $5692 \mathrm{~kg} \mathrm{ha}^{-1}$ was recorded at the highest nitrogen rate of $138 \mathrm{Kg} \mathrm{ha}^{-1}$ and it was at par with nitrogen rate of 46 $\mathrm{Kg} \mathrm{ha}^{-1}$. The lowest grain yield of $3867 \mathrm{~kg} \mathrm{ha}^{-1}$ was recorded in nitrogen rate of $0 \mathrm{Kg} \mathrm{ha}^{-1}$.

In line with applied $\mathrm{N}$, application of $\mathrm{P}$ increased rice grain yield through its effects on major yield attributes such as number of panicles per $\mathrm{m}^{2}$ and spikelets per panicle. [12] also reported similar response in rice yield and yield components to increasing rates of applied P fertilizer. Increase in the magnitude of yield attributes is associated with better root growth and increased uptake of nutrients favoring better growth of the crop [4]. Phosphorus application has also improved number of panicles per $\mathrm{m}^{2}$, panicle length and plant height thereby indirectly contributing to increment in grain yield.

Year had a significant influence on nitrogen as there was a significant $(p<0.05)$ year $\times$ nitrogen interaction on grain yield of rice (Table $1 \& 3$ ). The significant $(P<0.05)$ year $\times$ nitrogen rate interaction on grain yield showed that rice had higher grain yield in $2014\left(6934.7 \mathrm{kgha}^{-1}\right)$ than in 2015 $\left(4450.9 \mathrm{~kg} \mathrm{ha}^{-1}\right)$ (Table 3). However, year $\times$ phosphorous interaction on grain yield showed that non-significant $(P>$ 0.05 ) difference by application of the treatments (Table 1).

Table 3. Yield and yield components of rice as influenced by year, phosphorus and nitrogen rates during 2014 and 2015.

\begin{tabular}{|c|c|c|c|c|c|c|c|}
\hline Source of variation & Grain yield kg/ha & No. of panicle $/ \mathrm{m}^{2}$ & No. of tiller/plant & No. of tiller $/ \mathrm{m}^{2}$ & Plant height & Panicle length & Straw Yield (t/ha) \\
\hline \multicolumn{8}{|l|}{ Year } \\
\hline 2014 & $6117.0 \mathrm{~A}$ & $282.03 \mathrm{~A}$ & $5.31 \mathrm{~A}$ & $298.92 \mathrm{~A}$ & $92.90 \mathrm{~A}$ & $22.62 \mathrm{~A}$ & $10.21 \mathrm{~A}$ \\
\hline 2015 & 3858.1B & 141.31B & $4.42 \mathrm{~B}$ & 168.92B & $80.75 \mathrm{~B}$ & $19.44 \mathrm{~B}$ & 4.97B \\
\hline LSD & 491.33 & 13.78 & 0.48 & 16.38 & 1.93 & 0.50 & 0.79 \\
\hline \multicolumn{8}{|l|}{ Phosphorous (P) } \\
\hline 0 & $4205.9 \mathrm{C}$ & $200.17 \mathrm{~B}$ & 4.59 & $222.14 \mathrm{~A}$ & $84.90 \mathrm{~B}$ & $20.74 \mathrm{~B}$ & $6.28 \mathrm{C}$ \\
\hline 20 & $5197.5 \mathrm{AB}$ & $214.6 \mathrm{AB}$ & 5.06 & $239.92 \mathrm{~A}$ & 86.8AB & $20.98 \mathrm{AB}$ & $8.15 \mathrm{AB}$ \\
\hline 30 & $5660.6 \mathrm{~A}$ & $220.46 \mathrm{~A}$ & 5.00 & $238.53 \mathrm{~A}$ & $89.43 \mathrm{~A}$ & $21.55 \mathrm{~A}$ & $8.76 \mathrm{~A}$ \\
\hline LSD & $694.85 * * *$ & 19.48 & 0.68 & 23.17 & 2.73 & 0.71 & 1.12 \\
\hline \multicolumn{8}{|l|}{ Nitrogen $(\mathrm{N})$} \\
\hline 0 & $3867.0 \mathrm{~B}$ & 192.64B & $4.57 \mathrm{~B}$ & 211.68B & $81.38 \mathrm{C}$ & 20.76 & $5.88 \mathrm{C}$ \\
\hline 46 & $5124.9 \mathrm{~A}$ & $214.13 \mathrm{~A}$ & $4.78 \mathrm{~B}$ & $238.79 \mathrm{~A}$ & $85.77 \mathrm{~B}$ & 21.13 & $6.95 \mathrm{BC}$ \\
\hline 92 & $5265.7 \mathrm{~A}$ & $216.28 \mathrm{~A}$ & $4.58 \mathrm{~B}$ & $237.11 \mathrm{~A}$ & 88.27B & 21.01 & $7.89 \mathrm{~B}$ \\
\hline LSD & $694.85 * * *$ & 19.48 & 0.68 & 23.17 & 2.73 & 0.71 & 1.12 \\
\hline CV\% & 24.14 & 15.96 & 24.32 & 17.17 & 5.46 & 5.88 & 25.77 \\
\hline
\end{tabular}

\subsubsection{Influence of Year and Nitrogen Interaction on Yield and Yield Components of Upland Rice}

There was a significant interaction of year $\times \mathrm{N}$ rates on grain yield $(\mathrm{p}<0.05)$, number of tiller per plant $(\mathrm{p}<0.05)$, number of tiller $/ \mathrm{m}^{2}(\mathrm{p}<0.01)$, plant height $(\mathrm{p}<0.001)$ and straw yield $(\mathrm{p}<0.05)$. The significant year $\times$ nitrogen rate interaction showed that the nitrogen produced higher grain yield at all nitrogen rates in 2014 than 2015. Grain yield was the lowest in 2015 when $\mathrm{N}$ fertilizer was not applied (Table 3 ). The highest grain yield $\left(6934.7 \mathrm{~kg} \mathrm{ha}^{-1}\right)$ was obtained from plot that received maximum nitrogen $138 \mathrm{~kg} \mathrm{ha}^{-1}$ during 2014 growing season, however statically analysis indicate that there were non-significant from plot that received $46 \& 92 \mathrm{~kg}$ nitrogen $\mathrm{ha}^{-1}$ of during 2014 growing season. Year x nitrogen was significant $(p<0.05)$ difference to number of tiller per plant. The significant year $\times$ nitrogen rate interaction showed that the nitrogen produced higher grain yield at all nitrogen rates in 2014 than 2015. The highest number of tiller per plant (6.31) was obtained from plot that fertilized maximum nitrogen (138 kg ha $\left.{ }^{-1}\right)$ during 2014 growing season. Also, the significant $(\mathrm{P}<0.01)$ influence of year $\times$ nitrogen interaction on number of tiller $/ \mathrm{m}^{2}$ showed that highest number of tiller $/ \mathrm{m}^{2}$ were observed in 2014 , the highest number of tiller $/ \mathrm{m}^{2}$ was obtained from $138 \mathrm{~kg} \mathrm{~N} \mathrm{ha}^{-1}$ (302.7), however ANOVAs table indicated that non- significant difference from $46 \& 92 \mathrm{~kg} \mathrm{~N} \mathrm{ha}^{-1}$ (Table 3). The same is true for plant height and straw yield of upland rice. The longest plant height $(101.6 \mathrm{~cm})$ and the highest straw yield $(13.73 \mathrm{t} / \mathrm{ha})$ was obtained from plot that fertilized with maximum nitrogen during 2014 than 2015. 
Table 4. Year $\times$ nitrogen fertilizers interaction on yield and yield components of rice, 2014 and 2015 .

\begin{tabular}{|c|c|c|c|c|c|c|c|}
\hline Nitrogen & Grain yield $\mathrm{kg} / \mathrm{ha}$ & No. of panicle $/ \mathrm{m}^{2}$ & No. of tiller/plant & No. of tiller $/ \mathrm{m}^{2}$ & Plant height (cm) & Panicle length (cm) & Straw Yield \\
\hline \multicolumn{8}{|l|}{2014} \\
\hline 0 & 4634.8B & 248.7 & $4.68 \mathrm{BC}$ & $257.6 \mathrm{~B}$ & $83.4 \mathrm{D}$ & $22.5 \mathrm{~A}$ & $7.42 \mathrm{D}$ \\
\hline 46 & $6319.2 \mathrm{~A}$ & 288.8 & $5.25 \mathrm{~B}$ & $312.4 \mathrm{~A}$ & $90.5 \mathrm{C}$ & $22.7 \mathrm{~A}$ & $9.03 \mathrm{C}$ \\
\hline 92 & $6579.4 \mathrm{~A}$ & 287.7 & $5.01 \mathrm{BC}$ & $302.8 \mathrm{~A}$ & 95.9B & $22.5 \mathrm{~A}$ & $10.67 \mathrm{~B}$ \\
\hline 138 & $6934.7 \mathrm{~A}$ & 302.7 & $6.31 \mathrm{~A}$ & $312.4 \mathrm{~A}$ & $101.6 \mathrm{~A}$ & $22.5 \mathrm{~A}$ & $13.75 \mathrm{~A}$ \\
\hline \multicolumn{8}{|l|}{2015} \\
\hline 0 & $3099.2 \mathrm{C}$ & 136.5 & 4.46BC & $165.7 \mathrm{C}$ & $79.3 \mathrm{E}$ & 18.9B & $4.35 \mathrm{E}$ \\
\hline 46 & $3930.5 \mathrm{C}$ & 139.3 & $4.31 \mathrm{BC}$ & $165.1 \mathrm{C}$ & 80.9DE & 19.4B & $4.87 \mathrm{E}$ \\
\hline 92 & $3951.9 \mathrm{BC}$ & 144.8 & $4.15 \mathrm{C}$ & $171.3 \mathrm{C}$ & $80.5 \mathrm{DE}$ & $19.4 \mathrm{~B}$ & $5.13 \mathrm{E}$ \\
\hline 138 & $4450.9 \mathrm{~B}$ & 144.5 & $4.76 \mathrm{BC}$ & $173.4 \mathrm{C}$ & $82.1 \mathrm{DE}$ & $19.8 \mathrm{~B}$ & $5.54 \mathrm{E}$ \\
\hline LSD & 982.6 & - & 0.96 & 32.7 & 3.8 & 1 & 1.59 \\
\hline CV\% & 24.14 & 15.96 & 24.32 & 17.17 & 5.46 & 5.88 & 25.77 \\
\hline
\end{tabular}

\subsubsection{Influence of Phosphorus and Nitrogen on Yield Components of Upland of Rice}

I. Panicles per square meter

Nitrogen application rates also significantly $(P<0.01)$ enhanced the number of panicles per square meter by $11.5 \%$ to $16.1 \%$ over zero-N, but there was no significant $(P<0.01)$ difference in panicle production observed among 46, 69 and $138 \mathrm{~kg} \mathrm{~N} \mathrm{ha}^{-1}$ (Table 2). Application of $\mathrm{N}$ up to $138 \mathrm{~kg} \mathrm{ha}^{-1}$ increased the number of panicles per $\mathrm{m}^{2}$ significantly $(P<$ 0.01 ) apparently by increasing the number of productive tillers (Table 2). This finding was in agreement with the results reported by [8]. The main effect of phosphorous fertilizers and the interaction effect of applied $\mathrm{N}$ and $\mathrm{P}$ levels on panicles per $\mathrm{m}^{2}$ (Table 1) was non-significant difference, however number of panicles per $\mathrm{m}^{2}$ increased with increasing the level of phosphorous fertilizers. The highest mean number of panicles per $\mathrm{m}^{2}\left(223.6 \mathrm{~m}^{-2}\right)$ was obtained with the applications of $138 \mathrm{~kg} \mathrm{~N}$ (Table 2), representing an increase of $16.1 \%$ (31 panicles per $\left.\mathrm{m}^{2}\right)$ over the control treatment. In conformity with the findings of the present study, [2] noted that panicle number is the most important factor that causes variation in the grain yield of rice.

II. Panicle length

The main effect of $\mathrm{N}$ and $\mathrm{P}$ had no significant $(p>0.05)$ influence on panicle length (Table 2$)$. The significant $(P<0.05)$ year $\times$ nitrogen rate interaction on panicle length showed that rice had longer panicle length in 2014 than in 2015. The highest panicle length was obtained from $46 \mathrm{~N} \mathrm{~kg} \mathrm{ha}^{-1}(22.7$ $\mathrm{cm})$, (Table 3). The effect of the interaction of nitrogen $x$ phosphorus rates on the panicle length of rice showed that mean yield increased with increments in $\mathrm{N}$ and $\mathrm{P}$ rates. With regards to the interaction between $\mathrm{N}$ and $\mathrm{P}$ fertilizers, the highest panicle length $(22.65 \mathrm{~cm})$ was obtained from the combination of $46 \mathrm{~kg} \mathrm{~N}$ and $30 \mathrm{~kg} \mathrm{P} \mathrm{ha}^{-1}$ (Table 4). Since one of the most important functions of $\mathrm{N}$ is promotion of rapid growth, application of $\mathrm{N}$ fertilizer increased panicle length of rice crop more than $\mathrm{P}$ fertilizer. In accordance to the findings reported by [20], panicle length has contributed to increment of rice grain yield indirectly by increasing the number of panicles per $\mathrm{m}^{2}$ and number of spikelets per panicle.
Table 5. Panicle length of rice as affected by $N \times P$ interaction during the 2014/2015 main cropping season.

\begin{tabular}{lllll}
\hline Nitrogen (N) & $\mathbf{P}$ & & & \\
\hline & $\mathbf{0}$ & $\mathbf{1 0}$ & $\mathbf{2 0}$ & $\mathbf{3 0}$ \\
\hline 0 & $21.16 \mathrm{BCD}$ & $20.70 \mathrm{BCD}$ & $20.98 \mathrm{BCD}$ & $20.20 \mathrm{D}$ \\
46 & $20.78 \mathrm{BCD}$ & $20.25 \mathrm{CD}$ & $20.85 \mathrm{BCD}$ & $22.65 \mathrm{~A}$ \\
92 & $20.70 \mathrm{BCD}$ & $20.73 \mathrm{BCD}$ & $20.98 \mathrm{BCD}$ & $21.65 \mathrm{ABC}$ \\
138 & $20.33 \mathrm{BCD}$ & $21.66 \mathrm{ABC}$ & $21.13 \mathrm{BCD}$ & $21.700 \mathrm{AB}$ \\
\hline
\end{tabular}

$\mathrm{N} * \mathrm{P}$ Interaction

Means followed by the same letter within a column or row are not significantly different at $5 \%$ level of significance; $\operatorname{LSD}(5 \%)=1.42$ to compare $\mathrm{N} \times \mathrm{P}$ interaction; $*$ = indicates significant difference at $5 \%$ level of significance; and $\mathrm{CV}$ $(\%)=5.88$

III. Plant Height

Plant height was significantly affected by application of $\mathrm{N}$ $(p<0.001)$ and $\mathrm{P}(p<0.01)$ main effects application (Table $2)$. As the level of nitrogen and phosphorous was increased the plant height was also increased. Nitrogen is a major contributor to crop growth, size and total dry matter production. The increase in height with increasing levels of $\mathrm{N}$ could not be explained better. While [19] in a similar study in Bida, Nigeria observed that there were significant increases in plant height with increasing levels of $\mathrm{N}$ when compared with the control. Increasing the levels of $\mathrm{N}$ up to $138 \mathrm{~kg} \mathrm{ha}^{-1}$ increased rice plant height significantly $(P<0.001)$ from $81.36 \mathrm{~cm} \mathrm{~cm}$ in the control treatment to $91.86 \mathrm{~cm}$ with the application of $138 \mathrm{~kg} \mathrm{~N} h a^{-1}$ (Table 2). The same as, plant height increased significantly $(P<0.01)$ with increasing applied $\mathrm{P}$ levels up to $30 \mathrm{~kg} \mathrm{P} \mathrm{ha}{ }^{-1}$ (Table 2). Increasing the levels of $\mathrm{P}$ up to $30 \mathrm{~kg} \mathrm{ha}^{-1}$ increased rice plant height significantly $(P<0.01)$ from $84.90 \mathrm{~cm}$ in the control treatment to $89.43 \mathrm{~cm}$ with the application of $138 \mathrm{~kg} \mathrm{~N} \mathrm{ha}^{-1}$ (Table 2).

\section{Straw yield}

The straw yield increased with increasing levels of $\mathrm{N}$ (Table 2). Straw yield increased from $5.88 \mathrm{tha}^{-1}$ at $0 \mathrm{~kg} \mathrm{~N} \mathrm{ha}^{-1}$ to a maximum of $9.65 \mathrm{t} \mathrm{ha}^{-1}$ at $138 \mathrm{~kg} \mathrm{~N} \mathrm{ha}^{-1}$. At $\mathrm{N}$ rates of 46,92 and $138 \mathrm{~kg} \mathrm{~N}^{-1}$, straw yield were significantly higher than 0 $\mathrm{kg} \mathrm{N} \mathrm{ha}{ }^{-1}$. At higher $\mathrm{N}$ rates of $138 \mathrm{~kg} \mathrm{~N}^{-1}$ significantly 
higher straw yields were produced. Straw yield increased by 1.07, 2.01 and $3.77 \mathrm{t} \mathrm{ha}^{-1}$ over the control for 46, 92 and 138 $\mathrm{kg} \mathrm{N} \mathrm{ha}{ }^{-1}$ respectively. The data in (Table 3) indicate that increasing the levels of applied $\mathrm{N}$ increased straw yield of rice significantly $(P<0.001)$ up to $138 \mathrm{~kg} \mathrm{~N} \mathrm{ha}^{-1}$. The results of the present study are in agreement with the findings of [2] who observed increasing dry matter accumulations due to increasing rates of applied mineral $\mathrm{N}$ fertilizer. This is attributed to enhanced plant $\mathrm{N}$ uptake [18] there by promoting vigorous vegetative growth of the rice crop plants.

Generally, straw yield increased from $5.88 \mathrm{t} \mathrm{ha}^{-1}$ in the control (no N) treatment to $9.65 \mathrm{t} \mathrm{ha}^{-1}$ with application of 138 $\mathrm{kg} \mathrm{N}^{-1}$ (Table 2). The same as straw yield increased with increasing levels of $\mathrm{P}$ (Table 2). Straw yield increased from $6.28 \mathrm{tha}^{-1}$ at $0 \mathrm{~kg} \mathrm{P} \mathrm{ha}^{-1}$ to a maximum of $8.76 \mathrm{t} \mathrm{ha}^{-1}$ at $30 \mathrm{~kg}$ $\mathrm{P} \mathrm{ha}^{-1}$. At $\mathrm{P}$ rates of 10, 20 and $30 \mathrm{~kg} \mathrm{P} \mathrm{ha}^{-1}$, straw yields were significantly higher than $0 \mathrm{~kg} \mathrm{P} \mathrm{ha}{ }^{-1}$. At higher $\mathrm{P}$ rates of 30 $\mathrm{kg} \mathrm{P} \mathrm{ha}{ }^{-1}$ significantly higher straw yields were produced. Likewise, [12] also reported that increasing rates of $P$ increased dry matter accumulation as a result of increased vegetative growth favored by enhanced nutrient uptake by rice plants. The data in Table 2 indicate that increasing the levels of applied $\mathrm{P}$ increased straw yield of rice significantly $(P<0.001)$ up to $30 \mathrm{~kg} \mathrm{P} \mathrm{ha}^{-1}$.

Table 6. Straw Yield of rice as affected by $N \times P$ interaction during the 2014/2015 main cropping season.

\begin{tabular}{lllll}
\hline Nitrogen (N) & $\mathbf{P}$ & & & \\
\hline & 0 & 10 & 20 & 30 \\
0 & $6.04 \mathrm{DEF}$ & $5.06 \mathrm{~F}$ & $6.48 \mathrm{CDEF}$ & $5.95 \mathrm{DEF}$ \\
46 & $5.54 \mathrm{EF}$ & $6.86 \mathrm{BCDEF}$ & $6.59 \mathrm{BCDEF}$ & $8.80 \mathrm{~B}$ \\
92 & $6.78 \mathrm{BCDEF}$ & $8.57 \mathrm{BC}$ & $7.61 \mathrm{BCDE}$ & $8.63 \mathrm{BC}$ \\
138 & $6.78 \mathrm{BCDEF}$ & $8.20 \mathrm{BCD}$ & $11.91 \mathrm{~A}$ & $11.68 \mathrm{~A}$ \\
\hline
\end{tabular}

$\mathrm{N} * \mathrm{P}$ Interaction
Means followed by the same letter within a column or row are not significantly different at $5 \%$ level of significance; $\operatorname{LSD}(5 \%)=2.25$ to compare $\mathrm{N} \times \mathrm{P}$ interaction; $*$ = indicates significant difference at $1 \%$ level of significance; and $\mathrm{CV}$ $(\%)=25.77$

Generally, straw yield increased from $6.28 \mathrm{t} \mathrm{ha}^{-1}$ in the control (no P) treatment to $8.76 \mathrm{t} \mathrm{ha}^{-1}$ with application of 30 $\mathrm{kg} \mathrm{P} \mathrm{ha}{ }^{-1}$ (Table 2). The significant $(P<0.05)$ year $\times$ nitrogen rate interaction on total straw yield showed that rice had higher straw yield in 2014 than in 2015, the higher straw yield was obtained in $2014\left(10.21 \mathrm{t} \mathrm{ha}^{-1}\right)$, (Table 2). The effect of the interaction of nitrogen $\times$ phosphorus rates on the straw yield of rice showed that mean yield increased with increments in $\mathrm{N}$ and $\mathrm{P}$ rates. With regards to the interaction between $\mathrm{N}$ and $\mathrm{P}$ fertilizers, the highest straw yield $(11.61 \mathrm{t}$ $\mathrm{ha}^{-1}$ ) was obtained from the combination of $138 \mathrm{~kg} \mathrm{~N}$ and 20 $\mathrm{kg} \mathrm{P} \mathrm{ha}{ }^{-1}$, however statically analysis indicate that nonsignificant difference with the combination of $138 \mathrm{~kg} \mathrm{~N}$ and $30 \mathrm{~kg} \mathrm{p} \mathrm{ha}{ }^{-1}$ (Table 5).

\subsection{Economic Analysis}

Economic analysis revealed that the gross return and net return were maximum with application of $46 \mathrm{~N}$ and $23 \mathrm{P}_{2} \mathrm{O}_{5}$ $\mathrm{kg} \mathrm{ha}^{-1}$ followed by application of $138 \mathrm{~N}$ and $69 \mathrm{P}_{2} \mathrm{O}_{5} \mathrm{~kg} \mathrm{ha}$ 1. Application of $46 \mathrm{~N}$ and $23 \mathrm{P}_{2} \mathrm{O}_{5} \mathrm{~kg} \mathrm{ha}^{-1}$ was well above the $100 \%$ minimum (CIMMYT, 1988). But investing on additional fertilizer rate gave less MRR. According to CIMMYT (1988) experience and empirical evidence, for the majority of situations indicated that the minimum rate of return acceptable to farmers would be between $50-100 \%$. Therefore, the treatments that have highest Marginal rate of return (MRR\%), w/c is application of $46 \mathrm{~N}$ and $23 \mathrm{P}_{2} \mathrm{O}_{5} \mathrm{~kg}$ $\mathrm{ha}^{-1} \mathrm{NP}$ for Rice production in Kamashi zone is recommended.

Table 7. Partial Budget Analysis of NP fertilizer application rates on Upland rice at Kamashi Zone.

\begin{tabular}{|c|c|c|c|c|c|c|c|c|}
\hline \multirow{2}{*}{ Treatments } & \multirow{2}{*}{$\begin{array}{l}\text { Total cost of } \\
\text { Production (ETB/ha) }\end{array}$} & \multicolumn{2}{|c|}{ Yield $\left(\mathrm{kg} \mathrm{ha}^{-1}\right)$} & \multicolumn{3}{|c|}{ Gross Return (ETB/ha) from } & \multirow{2}{*}{ Net return } & \multirow{2}{*}{$\begin{array}{l}\text { Marginal rate } \\
\text { of return }\end{array}$} \\
\hline & & Straw & Grain & Grain yield & Straw yield & Total & & \\
\hline \multicolumn{9}{|l|}{$\mathrm{P} \mathrm{kg} \mathrm{ha}^{-1}$} \\
\hline 0 & 3375.0 & 6080 & 3785.3 & 47316.4 & 608 & 47924.4 & 44549.4 & \\
\hline 10 & 4312.5 & 7060 & 4397.8 & 54972.0 & 706 & 55678.0 & 51365.5 & 727 \\
\hline 20 & 5250.0 & 8020 & 4677.8 & 58471.9 & 802 & 59273.9 & 54023.9 & 284 \\
\hline 30 & 6187.5 & 9205 & 5094.5 & 63681.8 & 920.5 & 64602.3 & 58414.8 & 468 \\
\hline \multicolumn{9}{|l|}{$\mathrm{N} \mathrm{kg} \mathrm{ha}^{-1}$} \\
\hline 0 & 3375.0 & 5885 & 3480.3 & 43503.8 & 588.5 & 44092.3 & 40717.3 & \\
\hline 46 & 4760.0 & 6950 & 4612.4 & 57655.1 & 695 & 58350.1 & 53590.1 & 929 \\
\hline 92 & 6145.0 & 7900 & 4739.1 & 59239.1 & 790 & 60029.1 & 53884.1 & 21 \\
\hline 138 & 7530.0 & 9645 & 5123.5 & 64044.0 & 964.5 & 65008.5 & 57478.5 & 259 \\
\hline
\end{tabular}

N. B: Prices - Urea $=9.85$ birr $/ \mathrm{kg}, \mathrm{DAP}=13.85 \mathrm{birr} / \mathrm{kg}, \mathrm{TSP}=18.75 \mathrm{birr} / \mathrm{kg}$, Price of Paddy Rice=12.50 birr $/ \mathrm{kg}$, Price of straw= $0.10 \mathrm{birr} / \mathrm{kg}$, Seed=10 birr $/ \mathrm{kg} \&$ Labor cost $=30 \mathrm{birr} /$ person/day for 8 hours, $\mathrm{TC}=$ Total cost, Gross return (Return from Grain \&straw yield) $=$ price $/ \mathrm{kg}^{*}$ yield in $\mathrm{kg}$ and Net return $=$ gross return - Total cost

\section{Recommendations and Conclusions}

The study was designed to determine the effects of Nitrogen and $\mathrm{P}$ fertilizer applications on grain yield and yield components of rice on Nitisols of Kamashi Zone District. The results obtained from this study showed that, grain yield and plant parameters were significantly $(\mathrm{P} \leq 0.001)$ influenced by the applied rates of nitrogen and/or phosphorous fertilizer. In this study, number of panicles per $\mathrm{m}^{2}$ and number of filled spikelet's per panicle as well as panicle length were the most important yield forming attributes causing significant variation in grain yield of rice. 
Panicle length contributed to grain yield increment indirectly by increasing the number of spikelets per panicle.

From this result, it can be concluded that farmers of Kamashi area need to apply a combination of $46 \mathrm{~kg} \mathrm{~N}$ and 10 $\mathrm{P} \mathrm{ha}^{-1}$ in order to improve the grain yield and yield components of rice on nitosols under rain fed conditions. Thus, in the light of the significant response of rice to both $\mathrm{N}$ and $\mathrm{P}$ fertilizers, further studies aimed at promoting integrated soil fertility management and formulation of fertilizer recommendation on soil test basis over locations are desirable.

\section{References}

[1] Christopher J. et al,. Rice Yield and Yield Components as Influenced by Phosphorus and Nitrogen Application Rates in the Moist Savanna of West Africa, Journal of Agricultural Science and Technology B 2 (2012) 1214-1223

[2] Heluf Gebrekidan and Mulugeta Seyoum, Effects of Mineral $\mathrm{N}$ and P Fertilizers on Yield and Yield Components of Flooded Lowland Rice on Vertisols of Fogera Plain, Ethiopia, Journal of Agriculture and Rural Development in the Tropics and Subtropics Volume 107, No. 2, 2006, pages 161-176

[3] K. A. Okeleye, A. A Oyekanmi, O. J. Ariyo, T. O. Tayo, Performance of rice varieties under upland and lowland rainfed ecologies of South Western Nigeria, Asset Series A 2 (2002) 127-140.

[4] Kumar, K. and Rao, K. V. P.; Nitrogen and phosphorus requirement of upland rice in Manipur; Oryza; 29: 306-309; 1992.

[5] Landon, J. R. 1991. Booker tropical soil manual: A Handbook for Soil Survey and Agricultural Land Evaluation in the Tropics and Subtropics. Longman Scientificand Technical, Essex, New York. 474p.

[6] Mengel K, EA Kirkby (1987). Principles of Plant Nutrition. (4th Ed.). International potash institute, Bern, Switzerland.

[7] Mulugeta Seyoum; Uptake and response of rice (Oryza sativa L.) to nitrogen and phosphorus fertilization under rain fed lowland condition of the Fogera Plain, Northern Ethiopia; Master's thesis; Alemaya University; 2000.

[8] Mulugeta Seyoum and Heluf Gebrekidan; Effects of N and P fertilisers on yield and $\mathrm{N}$ uptake of flooded rice grown on Vertisols of Fogera Plain of Ethiopia; Indian Journal of Fertilizers; 1 (1): 47-51; 2005.

[9] Ni-Wuzhong, He-Nianzu, Ni-Wz and He-Nz; Effect of excess fertilizer phosphorus on some chemical properties of paddy soil derived from red soil and its relation to rice growth; (Abstract), Institution of Soil Sci. Academia Sinica; 7: 1; 1997.
[10] S. O. Fagade, Yield gaps and productivity decline in rice production in Nigeria, in: Proceedings of the Expert Consultation on Yield Gap and Productivity Decline in Rice, FAO Rome, 2000.

[11] S. O. Oikeh, S. Nwilene, S. Diatta, O. Osiname, A. Toure, K. A. Okeleye, Responses of upland NERICA rice to nitrogen and phosphorus in the forest agro-ecosystems, Agron. J. 100 (2008) 735-741.

[12] Zaman, S. K., Razzque, M. A., Karim, S. M. R. and Bhuiyan, N. I.; Rice response to phosphorus in wetland soil; Pakistan J. Sci.; 38: 11-12; 1995.

[13] J. M. Jibrin, S. Oikeh, M. A. Hussaini, S. Miko, B. M. Shehu, M. Sie, Responses of lowland NERICA and improved Oryza sativa to phosphorus and nitrogen in Sudan savanna agroecosystem, J. Agri. Sci. and Tech. 4 (2010) 47-56.

[14] S. O. Oikeh, S. Nwilene, S. Diatta, O. Osiname, A. Toure, K. A. Okeleye, Responses of upland NERICA rice to nitrogen and phosphorus in the forest agro-ecosystems, Agron. J. 100 (2008) 735-741.

[15] Kamara AY, Ekelene F, Omoigu KO, Chikoye D (2011). Influence of nitrogen fertilization on yield and yield components of rain-fed lowland NERICA rice in the northern Guinea Savanna of Nigeria. Afr. J. Agric. Res. Vol. 6 (13): 3092-3097.

[16] FAO (2011). Food and Agricultural Organization of the United Nations Current World Fertilizer Trends and Outlook to 2015.

[17] J. M. Jibrin, S. Oikeh, M. A. Hussaini, S. Miko, B. M. Shehu, M. Sie, Responses of lowland NERICA and improved Oryza sativa to phosphorus and nitrogen in Sudan savanna agroecosystem, J. Agri. Sci. and Tech. 4 (2010) 47-56.

[18] Dalal, P. K. and Dixit, L.; Response of newly developed medium duration and high yielding rice genotypes to nitrogen; Indian J. Agron:; 30 (1): 114-116; 1987.

[19] Ethan S, Odunze AC, Abu ST, Iwuafor ENO (2011). Effect of water management and nitrogen rates on $\mathrm{Fe}$ concentration and yield in lowland rice. Agric. Bio. J. N. Am. 2011, 2 (4): 622629.

[20] Behera, A. K.; Response of scented rice (Oryza sativa) to nitrogen under transplanted conditio n; Indian J. Agron.; 43 (1): 64-67; 1998.

[21] CIMMT, 1988. From agronomic data to farmer recommendations: An Economics training manual. Completely revised edition. Mexico, D. F.

[22] The Federal Democratic Republic of Ethiopia, Ministry of Agriculture (MoA), 2010. National Rice Research and Development Strategy of Ethiopia, Addis Ababa, Ethiopia. 